\title{
Phlebovirus seroprevalence in Austrian Army personnel returning from missions abroad
}

\author{
Edwin Kniha' ${ }^{1}$, Adelheid G. Obwaller ${ }^{1,2}$, Gerhard Dobler ${ }^{3}$, Wolfgang Poeppl ${ }^{4,5}$, Gerhard Mooseder ${ }^{5}$ \\ and Julia Walochnik ${ }^{1 *}$ (1)
}

\begin{abstract}
Background: Phleboviruses are mainly transmitted by sand flies and infections can result in various symptoms, including meningitis and meningoencephalitis. In endemic regions, seroprevalences in humans and animals are high. Military personnel on missions in endemic areas are at increased risk of infection, however, for soldiers from central European countries, data are scarce. The aims of this study were to determine the exposure to phleboviruses of Austrian soldiers returning from missions abroad and to assess potential risk factors. A retrospective serological study was performed with sera of 753 healthy Austrian soldiers returning from missions in Bosnia and Herzegovina (BIH, $n=61)$, Kosovo $(n=261)$, Syria $(n=101)$ and Lebanon $(n=63)$ and of soldiers prior to their missions $(n=267)$.

Results: Altogether, 119 sera (15.8\%, 119/753) were positive for anti-Phlebovirus lgG antibodies, with highest seroprevalences found in soldiers returning from Kosovo (20.69\%, 54/261), followed by Syria (17.82\%, 18/101), Lebanon $(14.29 \%, 9 / 63)$ and $\mathrm{BIH}(11.48 \%, 7 / 61)$. Of the soldiers tested prior to their missions $11.61 \%(31 / 267)$ were positive. Of the 119 seropositive individuals, 30 (25.2\%, 30/119) also had anti-Phlebovirus IgM antibodies. Phlebovirus seropositivity significantly correlated with symptoms of febrile illness during the respective mission (OR: 1.9, 95\% Cl: 1.1-3.4, $P=0.03$ ) and with Leishmania seropositivity (OR: 2.7, 95\% Cl: 1.2-5.8, $P=0.009)$. Also, the outdoor activity "running" during the mission showed a strong trend towards an association with Phlebovirus seropositivity (OR: 1.9, 95\% Cl: 0.9$4.4, P=0.08$ ), and seropositivity generally increased with the duration of a mission (OR: $2.5,95 \% \mathrm{Cl}: 0.9-7.5, P=0.07$ ).

Conclusions: This study indicates that soldiers are exposed to sand flies and at significant risk for Phlebovirus infection during missions in the Mediterranean area and the Middle East. Adequate prevention measures should be applied particularly during vespertine outdoor activities.
\end{abstract}

Keywords: Sand fly fever, Military, Sand fly, Risk factors, Balkans, Middle East

\section{Background}

Phleboviruses are transmitted by either sand flies, mosquitoes or ticks, with sand flies being the main vectors [1]. Among various described species, Toscana virus (TOSV), Sand fly fever Naples phlebovirus (SFNV), Sand fly fever Sicilian virus (SFSV) and Cyprus virus (CYPV), all occurring in the Mediterranean regions of Europe, Africa and Asia, are of highest medical relevance. Phlebovirus infections often remain asymptomatic, but can

\footnotetext{
*Correspondence: julia.walochnik@meduniwien.ac.at

${ }^{1}$ Institute of Specific Prophylaxis and Tropical Medicine, Center for Pathophysiology, Infectiology and Immunology, Medical University of Vienna, Vienna, Austria

Full list of author information is available at the end of the article
}

result in febrile illness with sudden high fever, headache, photophobia, malaise and retro-orbital pain, symptoms usually declining after a few days [2]. However, Toscana virus shows a strong neurotropism and is assumed to be majorly responsible for meningitis and meningoencephalitis during the summer months in Italy [2]. Further reports from endemic countries such as Portugal [3], France [4] and Spain [5] and an imported case in Switzerland [6] corroborate Toscana virus being an important cause of meningitis in Mediterranean countries. To date, no vaccine or specific drugs are available, but assumedly lifelong immunity to the respective Phlebovirus serotype is established after infection [7]. 
Sand fly fever has been known to be of considerable medical importance in military personnel for decades [8], particularly when large numbers of immunologically naïve soldiers are introduced to Phlebovirus-endemic regions [9]. Symptomatic as well as asymptomatic infections in military troops have been reported from various regions [10]. Outbreaks of sand fly fever have occurred in military personnel operating in Cyprus and Iraq $[11,12]$. UK military personnel was shown to be exposed to sand flies and phleboviruses in Afghanistan and high numbers of sand fly fever virus infections were reported from military personnel deployed in Iran $[13,14]$.

The Austrian Armed Forces operate in several sand flyendemic areas. Here, a retrospective serological study was performed in order to evaluate Phlebovirus seroprevalences among healthy Austrian soldiers returning from sand fly-endemic operational areas.

\section{Methods}

\section{Serum samples}

Altogether, 753 sera, all taken during routine medical examinations, were included in this study. Study participants showed a minimum age of 18 and a maximum age of 63 years (mean $\pm S D, 29.6 \pm 10.04$ ). Of the 753 participants, 747 were male and 6 were female; 486 sera derived from healthy soldiers after their return from missions abroad, i.e. 61 samples from soldiers returning from $\mathrm{BIH}$, 101 from Syria and 63 from Lebanon, all collected in June and July 2013, and 261 samples from soldiers returning from Kosovo, collected between March and April 2015. For comparison, 267 sera of soldiers prior to their missions, collected between April and September 2009, were included in the study. These soldiers had never been on a mission and their last vacation was at least 6 months ago. Sera were kept at $-20^{\circ} \mathrm{C}$ until use.

\section{Study design}

All patients were asked to fill out a detailed questionnaire. Demographic data, including age, sex and place of residence were collected. Additionally, information on the status of employment (professional soldier, militiamen), duration of the current mission, vacation during the mission, information on prior and on outdoor activities and animal contact during the mission was obtained. Data on Leishmania spp. seropositivity was available for the provided sera $[15,16]$.

\section{Seroprevalence}

All 753 sera were tested for IgG antibodies by an indirect immunofluorescence test (Euroimmun, Lübeck, Germany) with subsequent fluorescence microscopy, following the manufacturer's directions. Serum samples were used at an initial dilution of 1:10. Positive samples were subsequently further diluted to assess titers of 1:20, 1:40, 1:80, 1:100, 1:320 and 1:1000, testing for IgG antibodies against TOSV, SFNV, SFSV and CYPV.

All IgG positive samples were additionally tested for IgM antibodies against TOSV, SFNV, SFSV and CYPV, by the indirect immunofluorescence test described above. To avoid false results by interfering IgG antibodies, samples were incubated with EUROSORB (Euroimmun, Lübeck, Germany) for $15 \mathrm{~min}$, subsequently centrifuged for $5 \mathrm{~min}$ at $2000 \times \mathrm{rpm}$ and the supernatant was used for further testing, following the manufacturer's directions as described above.

\section{Statistical analysis}

Numerical data are presented as the mean and standard deviation (SD). A Mann-Whitney U-test was performed to evaluate differences between operational areas. Categorical data was analysed by a Fisher's exact test, using Phlebovirus seropositivity as a predictor variable. Odds ratios $(\mathrm{OR})$ with exact $95 \%$ confidence intervals $(\mathrm{CI})$ were estimated. A two-sided $P$-value $<0.05$ was considered statistically significant. All positive samples were included to calculate seroprevalences. Titers of 1:10 were excluded from the analysis to test risk factors associated with Phlebovirus seropositivity, as duration of mission and risk of infection by season. The risk of transmission was calculated based on the presence of a soldier during sand fly activity in the respective operational area. Presence during June, July and August was rated as high infection risk. Presence during two of the three months was rated as medium risk and presence during one or none of the three summer months was rated as low risk. Microsoft Excel 2011 for Mac and the R environment for Mac were used for data analysis.

\section{Results}

\section{Seroprevalences}

Altogether, 119 sera $(15.8 \%, 119 / 753)$ showed IgG antibodies against phleboviruses. All 6 female soldiers included in the study were negative. No significant difference was observed between professional soldiers and militiamen (OR: 1.2, 95\% CI: $0.8-1.8 \%, P=0.48$ ). Soldiers tested after their missions showed a significantly higher seroprevalence $(18.1 \%, 88 / 486)$, than soldiers tested prior to their missions $(11.6 \%, 31 / 267$; OR: $1.7,95 \%$ CI: $1.1-$ $2.8 \%, P=0.02)$. No significant differences were observed between the age groups. Seropositivity was observed in all age groups of soldiers returning from operational areas. In soldiers investigated prior to their missions only the age groups $<30$ and $30-39$ showed seropositivity, however sample sizes of older age groups were too low for statistical analysis (Table 1). 
Table 1 Seroprevalences by age

\begin{tabular}{|c|c|c|c|c|c|}
\hline & Age group (years) & Positive/Total (\%) & OR & $95 \% \mathrm{Cl}$ & $P$-value \\
\hline \multirow[t]{4}{*}{ Operational areas } & $<30$ & $33 / 252(13.1)$ & Reference & & \\
\hline & $30-39$ & 8/95 (8.4) & 0.6 & $0.2-1.4$ & 0.2 \\
\hline & $40-49$ & 16/99 (16.2) & 1.3 & $0.6-2.5$ & 0.5 \\
\hline & $>50$ & $4 / 40(10.0)$ & 0.7 & $0.2-2.0$ & 0.6 \\
\hline \multirow[t]{4}{*}{ Without prior mission } & $<30$ & $10 / 232(4.3)$ & Reference & & \\
\hline & $30-39$ & $2 / 26(7.7)$ & 1.8 & $0.2-9.1$ & 0.4 \\
\hline & $40-49$ & $0 / 7(0)$ & - & - & - \\
\hline & $>50$ & $0 / 2(0)$ & - & - & - \\
\hline
\end{tabular}

Table 2 Titers by operational areas

\begin{tabular}{|c|c|c|c|c|c|c|c|c|c|}
\hline & & $1: 10$ & $1: 20$ & $1: 40$ & $1: 80$ & $1: 100$ & $1: 320$ & $1: 1000$ & Total \\
\hline \multirow[t]{5}{*}{$\lg G$} & Without prior mission & $\begin{array}{l}8 / 267 \\
(2.99 \%)\end{array}$ & $\begin{array}{l}3 / 267 \\
(1.12 \%)\end{array}$ & $\begin{array}{l}4 / 267 \\
(1.50 \%)\end{array}$ & $\begin{array}{l}4 / 267 \\
(1.50 \%)\end{array}$ & $\begin{array}{l}3 / 267 \\
(1.12 \%)\end{array}$ & $\begin{array}{l}9 / 267 \\
(3.37 \%)\end{array}$ & - & $\begin{array}{l}31 / 267 \\
(11.6 \%)\end{array}$ \\
\hline & $\mathrm{BlH}$ & - & $\begin{array}{l}1 / 61 \\
(1.64 \%)\end{array}$ & $\begin{array}{l}1 / 61 \\
(1.64 \%)\end{array}$ & $\begin{array}{l}2 / 61 \\
(3.28 \%)\end{array}$ & $\begin{array}{l}3 / 61 \\
(4.92 \%)\end{array}$ & - & - & $\begin{array}{l}7 / 61 \\
(11.47 \%)\end{array}$ \\
\hline & Kosovo & $\begin{array}{l}23 / 261 \\
(8.81 \%)\end{array}$ & $\begin{array}{l}3 / 261 \\
(1.15 \%)\end{array}$ & $\begin{array}{l}11 / 261 \\
(4.21 \%)\end{array}$ & $\begin{array}{l}3 / 261 \\
(1.15 \%)\end{array}$ & $\begin{array}{l}6 / 261 \\
(2.30 \%)\end{array}$ & $\begin{array}{l}7 / 261 \\
(2.68 \%)\end{array}$ & $\begin{array}{l}1 / 261 \\
(0.38 \%)\end{array}$ & $\begin{array}{l}54 / 261 \\
(20.69 \%)\end{array}$ \\
\hline & Syria & $\begin{array}{l}3 / 101 \\
(2.97 \%)\end{array}$ & $\begin{array}{l}2 / 101 \\
(1.98 \%)\end{array}$ & $\begin{array}{l}4 / 101 \\
(3.96 \%)\end{array}$ & $\begin{array}{l}1 / 101 \\
(0.99 \%)\end{array}$ & $\begin{array}{l}3 / 101 \\
(2.97 \%)\end{array}$ & $\begin{array}{l}5 / 101 \\
(4.95 \%)\end{array}$ & - & $\begin{array}{l}\text { 18/101 } \\
(17.82 \%)\end{array}$ \\
\hline & Lebanon & $\begin{array}{l}1 / 63 \\
(1.59 \%)\end{array}$ & $\begin{array}{l}1 / 63 \\
(1.59 \%)\end{array}$ & - & $\begin{array}{l}1 / 63 \\
(1.59 \%)\end{array}$ & $\begin{array}{l}3 / 63 \\
(4.76 \%)\end{array}$ & - & $\begin{array}{l}3 / 63 \\
(4.76 \%)\end{array}$ & $\begin{array}{l}9 / 63 \\
(14.28 \%)\end{array}$ \\
\hline \multirow[t]{5}{*}{$\lg M^{a}$} & Without prior mission & $\begin{array}{l}2 / 31 \\
(6.45 \%)\end{array}$ & $\begin{array}{l}3 / 31 \\
(9.68 \%)\end{array}$ & $\begin{array}{l}3 / 31 \\
(9.68 \%)\end{array}$ & & $\begin{array}{l}2 / 31 \\
(6.45 \%)\end{array}$ & - & - & $\begin{array}{l}10 / 31 \\
(32.25 \%)\end{array}$ \\
\hline & $\mathrm{BIH}$ & - & - & - & - & - & - & - & $\begin{array}{l}0 / 7 \\
(0.00 \%)\end{array}$ \\
\hline & Kosovo & $\begin{array}{l}5 / 54 \\
(9.26 \%)\end{array}$ & $\begin{array}{l}5 / 54 \\
(9.26 \%)\end{array}$ & - & $\begin{array}{l}2 / 54 \\
(3.70 \%)\end{array}$ & $\begin{array}{l}4 / 54 \\
(7.41 \%)\end{array}$ & - & - & $\begin{array}{l}16 / 54 \\
(29.63 \%)\end{array}$ \\
\hline & Syria & - & $\begin{array}{l}1 / 18 \\
(5.55 \%)\end{array}$ & - & $\begin{array}{l}1 / 18 \\
(5.55 \%)\end{array}$ & $\begin{array}{l}1 / 18 \\
(5.55 \%)\end{array}$ & - & - & $\begin{array}{l}3 / 18 \\
(16.67 \%)\end{array}$ \\
\hline & Lebanon & - & $\begin{array}{l}1 / 9 \\
(11.11 \%)\end{array}$ & - & - & - & - & - & $\begin{array}{l}1 / 9 \\
(11.11 \%)\end{array}$ \\
\hline
\end{tabular}

a Only lgG positive samples tested

Of the 119 IgG positive sera, 30 (25.2\%, 30/119) also showed IgM antibodies against phleboviruses. Soldiers tested after their missions showed a lower IgM seroprevalence $(22.7 \%, 20 / 88)$, than soldiers tested prior to their missions (32.3\%, 10/31; OR: 0.6, 95\% CI: 0.2-1.7\%, $P=0.39$ ) (Table 2).

\section{Geographical differences}

Seroprevalences varied between the operational areas, being highest in soldiers returning from Kosovo (20.7\%, $54 / 261)$, followed by Syria $(17.8 \%, 18 / 101)$, Lebanon $(14.3 \%, 9 / 63)$ and BIH $(11.5 \%, 7 / 61)$ (Table 3$)$.

Highest rates of IgM seropositivity were observed in soldiers returning from Kosovo $(29.6 \%, 16 / 54)$, followed by Syria $(16.7 \%, 3 / 18)$ and Lebanon $(11.1 \%, 1 / 9)$. No
IgM titers were detected in soldiers returning from $\mathrm{BIH}$ (Table 2).

\section{Titers}

IgG titers ranged from 1:10 to $1: 1000$ in soldiers returning from a mission, being highest in soldiers returning from Kosovo and Lebanon (1:1000), followed by Syria (1:320) and BIH (1:100). IgG titers in soldiers who had never been on a mission ranged from $1: 10$ to $1: 320$ (Table 2).

IgM titers ranged from 1:10 to 1:100 in soldiers returning from a mission, being highest in soldiers returning from Kosovo and Syria (1:100). IgM titers in soldiers who had not been on a mission also ranged from 1:10 to $1: 100$ (Table 2). 
Table 3 Seroprevalences by operational areas

\begin{tabular}{|c|c|c|c|c|c|c|}
\hline & \multicolumn{2}{|l|}{ Titer $\geq 1: 10$} & \multicolumn{2}{|l|}{ Titer $\geq 1: 20$} & \multicolumn{2}{|l|}{ Titer $\geq 1: 100$} \\
\hline & $\begin{array}{l}\text { IgG positive/Total } \\
(\%)\end{array}$ & $\begin{array}{l}\text { OR/95\% Cl } \\
\text { (P-value) }\end{array}$ & $\begin{array}{l}\text { lgG positive/Total } \\
(\%)\end{array}$ & $\begin{array}{l}\text { OR/95\% Cl } \\
\text { (P-value) }\end{array}$ & $\begin{array}{l}\text { IgG positive/Total } \\
(\%)\end{array}$ & $\begin{array}{l}\text { OR/95\% Cl } \\
\text { (P-value) }\end{array}$ \\
\hline $\begin{array}{l}\text { Soldiers before mis- } \\
\text { sions }\end{array}$ & $\begin{array}{l}31 / 267 \\
(11.6)\end{array}$ & Reference & $\begin{array}{l}23 / 267 \\
(8.6 \%)\end{array}$ & Reference & $\begin{array}{l}12 / 267 \\
(4.5)\end{array}$ & Reference \\
\hline $\mathrm{BIH}$ & $\begin{array}{l}7 / 61 \\
(11.5)\end{array}$ & $\begin{array}{l}1.0 / 0.4-2.5 \\
(1.0)\end{array}$ & $\begin{array}{l}7 / 61 \\
(11.5 \%)\end{array}$ & $\begin{array}{l}1.4 / 0.5-3.5 \\
(0.46)\end{array}$ & $\begin{array}{l}3 / 61 \\
(4.9)\end{array}$ & $\begin{array}{l}1.1 / 0.2-4.3 \\
(1.0)\end{array}$ \\
\hline Kosovo & $\begin{array}{l}54 / 261 \\
(20.7)\end{array}$ & $\begin{array}{l}1.9 / 1.2-3.2 \\
(0.006)^{*}\end{array}$ & $\begin{array}{l}31 / 261 \\
(11.9 \%)\end{array}$ & $\begin{array}{l}1.5 / 0.8-2.7 \\
(0.25)\end{array}$ & $\begin{array}{l}14 / 261 \\
(5.4)\end{array}$ & $\begin{array}{l}1.2 / 0.5-2.9 \\
(0.70)\end{array}$ \\
\hline Syria & $\begin{array}{l}18 / 101 \\
(17.8)\end{array}$ & $\begin{array}{l}1.7 / 0.8-3.2 \\
(0.12)\end{array}$ & $\begin{array}{l}15 / 101 \\
(14.9 \%)\end{array}$ & $\begin{array}{l}2.0 / 0.9-4.3 \\
(0.05)^{*}\end{array}$ & $\begin{array}{l}8 / 101 \\
(7.9)\end{array}$ & $\begin{array}{l}1.8 / 0.6-5.0 \\
(0.20)\end{array}$ \\
\hline Lebanon & $\begin{array}{l}9 / 63 \\
(14.3)\end{array}$ & $\begin{array}{l}1.3 / 0.5-3.0 \\
(0.50)\end{array}$ & $\begin{array}{l}8 / 63 \\
(12.7)\end{array}$ & $\begin{array}{l}1.7 / 0.6-4.2 \\
(0.22)\end{array}$ & $\begin{array}{l}6 / 63 \\
(9.5)\end{array}$ & $\begin{array}{l}2.23 / 0.7-6.8 \\
(0.13)\end{array}$ \\
\hline
\end{tabular}

* Significant result $(P<0.05)$

\section{Risk factors}

In soldiers returning from operational areas, a significant correlation was observed between Phlebovirus seropositivity and at least one of the following symptoms: febrile illness, fever, nausea, malaise, limb and joint pain (OR: 1.9, 95\% CI: 1.1-3.4, $P=0.03$ ). Moreover, a significant correlation between Phlebovirus seropositivity and having had an episode of fever during the mission was observed (OR: 2.3, 95\% CI: 1.03-4.6, $P=0.03$ ) (Table 4). Also, there was a significant correlation between antiPhlebovirus antibodies and anti-Leishmania antibodies (OR: 2.7, 95\% CI: 1.2-5.8, P=0.009) (Table 4).

A strong trend towards a correlation was observed between anti-Phlebovirus antibodies and the outdoor activity "running" during the respective mission (OR: 1.9, 95\% CI: $0.9-4.4, P=0.08$ ) (Table 4). Seropositivity in soldiers having been on a mission for more than 11 months was more than double compared to soldiers having been on a mission for less than six months (OR: 2.5, 95\% CI: 0.9-7.5, $P=0.07$ ) (Table 5). Finally, seropositivity increased by 1.7 -fold from low transmission risk (mission mainly not during summer) to high transmission risk (mission mainly during summer) (Table 6).

\section{Phlebovirus serotypes}

Although Phlebovirus diversity was not the focus of this study and the discriminatory power of the indirect immunofluorescence test is known to be low, the results for the different Phlebovirus serotypes are included for completeness. Generally, TOSV was always the most prevalent serotype (Table 7).

IgG antibodies against all four Phlebovirus serotypes were detected in soldiers returning from a mission and against three seroptypes (TOSV, SFNV and SFSV) in soldiers who had not been on a mission. While IgG antibodies against TOSV and SFSV were found in soldiers from
Table 4 Risk factors for Phlebovirus seropositivity during a mission

\begin{tabular}{|c|c|c|c|}
\hline Risk factors & OR & $95 \% \mathrm{Cl}$ & $P$-value \\
\hline \multicolumn{4}{|l|}{ Missions } \\
\hline Prior mission & 0.80 & $0.5-1.4$ & 0.50 \\
\hline Kosovo & 0.70 & $0.3-1.3$ & 0.29 \\
\hline Syria & 1.22 & $0.6-2.7$ & 0.60 \\
\hline Bosnia & 1.33 & $0.5-2.9$ & 0.53 \\
\hline \multicolumn{4}{|l|}{ Symptoms } \\
\hline Symptoms & 1.90 & $1.1-3.4$ & $0.03^{*}$ \\
\hline Fever & 2.30 & $1.03-4.6$ & $0.03^{*}$ \\
\hline Limb pain & 1.03 & $0.3-3.1$ & 1 \\
\hline Vacation & 1.88 & $0.9-4.1$ & 0.12 \\
\hline \multicolumn{4}{|l|}{ Outdoor activities } \\
\hline Sports & 1.40 & $0.5-4.6$ & 0.70 \\
\hline Running & 1.90 & $0.9-4.4$ & $0.08^{\mathrm{a}}$ \\
\hline Mountaineering & 1.17 & $0.6-2.1$ & 0.60 \\
\hline Cycling & 0.97 & $0.5-2.0$ & 1.0 \\
\hline Football & 1.00 & $0.1-4.5$ & 1.0 \\
\hline \multicolumn{4}{|l|}{ Animal contact } \\
\hline Dog & 1.10 & $0.6-2.0$ & 0.80 \\
\hline Cat & 1.40 & $0.7-2.6$ & 0.27 \\
\hline Rodent & 1.40 & $0.03-12.8$ & 0.50 \\
\hline Pets & 1.12 & $0.7-2.2$ & 0.50 \\
\hline \multicolumn{4}{|l|}{ Leishmania spp. ELISA } \\
\hline Leishmania antibodies & 1.50 & $0.7-3.0$ & 0.20 \\
\hline Leishmania positive & 2.70 & $1.2-5.8$ & $0.009^{*}$ \\
\hline Leishmania borderline & 0.60 & $0.1-2.0$ & 0.60 \\
\hline
\end{tabular}

* Significant result $(P<0.05)$

a Strong trend

all operational areas, IgG antibodies against CYPV were only found in soldiers returning from BIH. IgG antibodies against SFNV were found in one sample each in soldiers returning from Syria and Lebanon, respectively. 
Table 5 Seroprevalence by duration of mission

\begin{tabular}{llllll}
\hline $\begin{array}{l}\text { Duration } \\
\text { (months) }\end{array}$ & Total & IgG positive (\%) & OR & $95 \% \mathrm{Cl}$ & $P$-value \\
\hline$<6$ & 84 & $7(8.33)$ & Reference & & \\
$6-11$ & 315 & $38(12.06)$ & 1.5 & $0.6-4.2$ & 0.44 \\
$>11$ & 87 & $16(18.39)$ & 2.5 & $0.9-7.5$ & 0.07 \\
\hline
\end{tabular}

Table 6 Seropositivity by risk of infection (sand fly activity)

\begin{tabular}{llllll}
\hline Risk of infection & Total & lgG positive (\%) & OR & $95 \% \mathrm{Cl}$ & $P$-value \\
\hline Low & 275 & $32(11.64)$ & Reference & & \\
Medium & 116 & $12(10.34)$ & 0.9 & $0.4-1.8$ & 0.90 \\
High & 95 & $17(17.89)$ & 1.7 & $0.8-3.3$ & 0.16 \\
\hline
\end{tabular}

Note: risk of infection calculated: high, June, July and August; medium, two of three (June, July, August); low, one of three (June, July, August) and other months

Table 7 Seroprevalences of Phlebovirus serotypes

\begin{tabular}{|c|c|c|c|c|c|}
\hline & & \multicolumn{2}{|c|}{ SFNV complex } & \multicolumn{2}{|c|}{ SFSV complex } \\
\hline & & TOSV & SFNV & SFSV & CYPV \\
\hline \multirow[t]{2}{*}{$\lg G$} & Without prior mission & $\begin{array}{l}22 / 31 \\
(71.0 \%)\end{array}$ & $\begin{array}{l}2 / 31 \\
(6.5 \%)\end{array}$ & $\begin{array}{l}7 / 31 \\
(22.5 \%)\end{array}$ & - \\
\hline & Operational areas & $\begin{array}{l}45 / 88 \\
(51.1 \%)\end{array}$ & $\begin{array}{l}2 / 88 \\
(2.3 \%)\end{array}$ & $\begin{array}{l}39 / 88 \\
(44.3 \%)\end{array}$ & $\begin{array}{l}2 / 88 \\
(2.3 \%)\end{array}$ \\
\hline \multirow[t]{2}{*}{$\lg M$} & Without prior mission & $\begin{array}{l}10 / 10^{\mathrm{a}} \\
(100 \%)\end{array}$ & - & - & - \\
\hline & Operational areas & $\begin{array}{l}13 / 20^{\mathrm{a}} \\
(65.0 \%)\end{array}$ & - & $\begin{array}{l}7 / 20^{\mathrm{a}} \\
(35.0 \%)\end{array}$ & - \\
\hline
\end{tabular}

a Percentage of the tested IgG positive samples

IgM antibodies against TOSV and SFSV were observed in soldiers returning from missions, while only TOSV was observed in soldiers who had not been on a mission.

\section{Discussion}

This is the first study on Phlebovirus seroprevalence in Austrian military personnel and, to the best of our knowledge, in central Europe in general. We found unexpectedly high seroprevalences in soldiers returning from various missions abroad, whereby percentages of seropositivity varied between the operational areas. Interestingly, seropositivity was significantly associated with having had an episode of febrile illness during the mission. Also, the presence of anti-Phlebovirus antibodies significantly correlated with the presence of anti-Leishmania antibodies. Moreover, Phlebovirus infections were associated with longer missions, missions during sand fly season and the outdoor activity "running" during the mission.
Although, anti-Phlebovirus antibodies were found in all groups tested, the percentage of seropositivity differed considerably between the geographical areas, even between geographically nearby areas, such as $\mathrm{BIH}$ and Kosovo, revealing $11.5 \%$ and $20.7 \%$ seropositivity, respectively. This is in good accordance with the literature. For BIH, Hukic \& Salimovic-Besic reported rather constant TOSV seroprevalences of $12.5 \%, 9.38 \%, 10.71 \%$ in 2006, 2007 and 2008 respectively [17]. For Kosovo, a SFSV seroprevalence of $9.6 \%$ was reported in 1976 [1] and a TOSV seroprevalence of $5.5 \%$ in 2011 [18], but in a recent study, a SFSV seroprevalence of up to $78.2 \%$ and a TOSV-seroprevalence of up to $11 \%$ was found in livestock [19].

To the best of our knowledge, the present study provides the first data on Phlebovirus epidemiology involving Syria and Lebanon, however, the circulation of sand fly fever viruses has been reported from the bordering countries Turkey and Iraq [20,21]. The presence of sand flies in Syria and Lebanon, of course, is evident by leishmaniasis being highly endemic in this region [22].

Seroprevalences in soldiers returning from a mission did not increase with age, as has been reported for Phlebovirus-endemic countries [23-25]. Seroprevalence, however, is probably rather linked to the time of having been exposed to infected sand flies than age, which would fit well to our observation that seropositivity correlated to the length of the respective missions. Typically, Old World sand flies are active between spring and autumn, with either one or two peaks of activity. A longer duration of the mission not only increases the chance of being bitten by sand flies, but a duration of more than 11 months also grants to include at least one sand fly activity peak. In British military personnel deployed to Afghanistan, increased infection rates were observed during the summer months [13]. In military personnel, there generally is a trend towards age-independent seroprevalences of vector-borne diseases [14].

The fact that relatively high seroprevalences, albeit at lower titers, were also found in soldiers tested prior to their missions gives rise to the question whether autochthonous infections can be acquired in Austria. Austria, a central European country, has recently been proven to have stable sand fly populations [26-28]; however, until now only the species $P$. mascittii has been found and the vectorial capacity of $P$. mascittii for phleboviruses has not yet been investigated. Although there have been singular reports of supposedly autochthonous Phlebovirus infections from other central European countries, we assume that the seropositivity rather reflects the overall very high travel activity of the Austrian population and of soldiers in particular. As Austrians typically spend their summer holidays in the nearby Mediterranean countries and as 
military personnel participating in missions abroad typically show an overall increased travel activity, the soldiers can be expected to have already travelled to several Phlebovirus endemic regions in their lives [15]. Thus, as they however, reported to have not been outside of Austria in the past six months, the fact that a considerable percentage of them was seropositive rather corroborates the known longevity of anti-Phlebovirus antibodies than indicating autochthonous infections in Austria. Infections with phleboviruses are assumed to cause a lifelong immunity against the respective Phlebovirus serotype [7].

Interestingly, a significant association between seropositivity and having had at least one symptom of a febrile illness during the mission was observed, the rates of symptomatically infected soldiers varying between the operational areas. While only $11.8 \%$ of seropositive soldiers returning from $\mathrm{BIH}$ reported symptoms such as febrile illness, fever, nausea, malaise, limb and joint pain, 30.6\% of the soldiers returning from Syria reported these symptoms. The data from the literature are controversial. Only one of nine Phlebovirus seropositive U.S. soldiers returning from Iraq reported a febrile illness [29]. Also, the majority of seropositive Iranian soldiers stationed at the Western border of Iran did not report any symptoms [14]. However, up to $70 \%$ of symptomatic Pakistani military personnel and $92.9 \%$ of US Army soldiers operating in Iraq reported an uncertain febrile illness with various symptoms, including high fever, headache, myalgia, malaise and severe performance reduction of up to one week [12,30]. Together with our findings, these reports highlight the diversity of etiopathologies of Phlebovirus infections.

A significant association was observed between Phlebovirus seropositivity and Leishmania seropositivity. Coinfections can be acquired if suitable sand fly species and both pathogens are present. Leishmania spp. are endemic in Kosovo, Syria and Lebanon [22, 31] and also vectorcompetent sand fly species, such as Phlebotomus papatasi and $P$. tobbi, occur in the investigated operational areas [32-34]. Similarly to Phlebovirus infections, Leishmania infections are often associated to unspecific symptoms and thus remain undiagnosed [16].

A clear trend was observed between the outdoor activity "running" and Phlebovirus seropositivity. During missions, the time for sports typically is the late afternoon and early evening, when temperatures drop to moderate levels in the respective regions. This coincides with the nocturnal activity of most sand fly species, increasing with sunset and decreasing with sunrise [35]. Moreover, running is typically associated with heavy sweating and high $\mathrm{CO}_{2}$ exhalation, thus, during stretching phases after the run, joggers are ideal blood-meal hosts for bloodsucking insects. Heavy sweating also leads to a reduced protection by repellents, if used at all. Reduced protection by repellents was for example reported for US soldiers deployed in Iraq as a result of heavy sweating during sleep [36]. The attraction of sand flies to $\mathrm{CO}_{2}$ and human odor could contribute to increased biting rates after running, as also assumed by van Thiel et al. [37], who observed an association between off-duty sports during late afternoon and sand fly attack rates. Finally, for off-duty activities, military personnel typically wear shorts and T-shirts instead of their long-sleeved uniforms.

The screening for anti-CYPV and anti-SFNV antibodies revealed that these two virus types both play a minor role in the areas tested. However, CYPV and SFNV are genetically rather similar to SFSV and TOSV, respectively, and thus not reliably distinguishable by serology. CYPV, discovered rather recently, has been isolated from febrile Greek soldiers in Cyprus [11]. The two anti-CYPV antibody positive sera of soldiers returning from $\mathrm{BIH}$ detected in the current study are assumed to be most likely the result of an infection acquired during a previous vacation in Cyprus.

This study has several limitations. First, due to logistic issues of the Austrian Armed Forces, either only sera obtained after or before a mission and not both were available for the soldiers participating in this study. Secondly, the retrospective design of the study does not allow to faultlessly conclude that all Phlebovirus infections were indeed acquired during the respective mission. Low titers, particularly, could be the result of infections acquired on previous missions or also during holiday travels. However, in many cases and from all operational areas relatively high titers were detected and often the assumption of a recent infection was also supported by detectable IgM titers. Finally, as mentioned before, the IIFT is susceptible to cross-reactions, which could impair the reliability of the results concerning Phlebovirus serotypes, but this does not affect the overall seroprevalences.

\section{Conclusions}

This study clearly indicates that soldiers are exposed to sand flies and are at significant risk to infection with phleboviruses during missions in southern Europe and the Middle East. Thus, Phlebovirus infections should be considered as differential diagnosis when military personnel show unspecific febrile symptoms during deployment in endemic areas and adequate prevention measures should be taken, including protective clothing and the usage of repellents during evening outdoor activities and finemeshed impregnated bed nets while sleeping. Moreover, the observed relatively high seropositivity in soldiers without previous mission indicates that also frequent vacation trips to endemic areas pose a considerable risk to acquire a Phlebovirus infection. 


\section{Abbreviations}

$\mathrm{BIH}$ : Bosnia and Herzegovina; IIFT: Indirect-immunofluorescence test; TOSV: Toscana virus; SFNV: Sand fly fever Naples phlebovirus; SFSV: Sand fly fever Sicilian virus; CYPV: Cyprus virus; SD: standard deviation; OR: odds ratio; Cl: confidence interval.

\section{Acknowledgements}

The authors thank Iveta Haefeli for technical support. We are also grateful to Guenther Schreiner and Bernhard Wardein for their kind support.

\section{Authors' contributions}

EK and JW designed the study, conducted laboratory testing, analysed the data and drafted the manuscript. AGO analysed the data, drafted, reviewed and approved the manuscript for submission. WP analysed the data, drafted, reviewed and approved the manuscript for submission. GM drafted, reviewed and approved the manuscript for submission. GD conducted laboratory testing, drafted, reviewed and approved the manuscript for submission. All authors read and approved the final manuscript.

\section{Funding}

The study was supported by the Austrian Federal Ministry of Defence and the Medical University of Vienna, Austria (Grant No. FA623A0503, BMLVS/2016). The funders had no role in the study design, data collection and analysis, decision to publish, or preparation of the manuscript.

\section{Availability of data and materials}

All data generated or analysed during this study are included in this article.

\section{Ethics approval and consent to participate}

This study was approved by the Ethics committee of the Austrian Armed Forces. All soldiers participated voluntarily. Informed written consent was obtained.

\section{Consent for publication}

Not applicable.

\section{Competing interests}

The authors declare that they have no competing interests.

\section{Author details \\ ${ }^{1}$ Institute of Specific Prophylaxis and Tropical Medicine, Center for Pathophysi- ology, Infectiology and Immunology, Medical University of Vienna, Vienna, Austria. ${ }^{2}$ Federal Ministry of Defence, Division of Science, Research and Devel- opment, Vienna, Austria. ${ }^{3}$ Bundeswehr Institute of Microbiology (BwIM), Munich, Germany. ${ }^{4}$ Department of Infectious Diseases and Tropical Medicine, Medical University of Vienna, Vienna, Austria. ${ }^{5}$ Department of Dermatology and Tropical Medicine, Military Medical Cluster East, Austrian Armed Forces, Vienna, Austria.}

Received: 10 May 2019 Accepted: 17 August 2019

Published online: 24 August 2019

\section{References}

1. Tesh RB, Saidi S, Gajdamovic JS, Rodhain F, Vesenjak-Hirjan J. Serological studies on the epidemiology of sandfly fever in the Old World. Bull World Health Organ. 1976;54:663-74.

2. Depaquit J, Grandadam M, Fouque F, Andry PE, Peyrefitte CN. Arthropodborne viruses transmitted by phlebotomine sandflies in Europe: a review. Euro Surveill. 2010;15:19507.

3. Santos L, Simões J, Costa R, Martins S, Lecour H, Service ID, et al. Toscana virus meningitis in Portugal, 2002-2005. Euro Surveill. 2007;12:E3-4.

4. Marlinge MC, Crespy L, Zandotti C, Piorkowski G, Kaphan E, Charrel RN, et al. Afebrile meningoencephalitis with transient central facial paralysis due to Toscana virus infection, south-eastern France, 2014. Euro Surveill. 2014;19:20974.

5. Navarro-Marí JM, Fernández-Roldán C, Pérez-Ruiz M, Sanbonmatsu S, de la Rosa M, Sánchez-Seco MP. Meningitis by Toscana virus in Spain: description of 17 cases. Med Clin (Barc). 2004;122:420-2.
6. Sonderegger B, Hächler H, Dobler G, Frei M. Imported aseptic meningitis due to Toscana virus acquired on the island of Elba, Italy, August 2008. Euro Surveill. 2009:14:19079.

7. Tesh RB. The Genus Phlebovirus and its vectors. Annu Rev Entomol. 1988:33:169-81.

8. Sabin AB, Philip C, Paul JR. Phlebotomus (papatacci or sandfly) fever: a disease of military importance, summary of existing knowledge and preliminary report of original investigations. J Am Med Assoc. 1944;125:693-9.

9. Alkan C, Bichaud L, De Lamballerie X, Alten B, Gould EA, Charrel RN. Sandfly-borne phleboviruses of Eurasia and Africa: epidemiology, genetic diversity, geographic range, control measures. Antiviral Res. 2013;100:54-74.

10. Gaĭdamovich SI, Khutoretskaia NV, Aziamov I, Tsiupa I, Mel'nikova EE. Virological study of cases of sandfly fever in Afghanistan. Vopr Virusol. 1990;35:45-7

11. Papa A, Konstantinou G, Pavlidou V, Antoniadis A. Sandfly fever virus outbreak in Cyprus. Clin Microbiol Infect. 2006;12:192-4.

12. Ellis SB, Appenzeller G, Lee H, Mullen K, Swenness R, Pimentel G, et al. Outbreak of sandfly fever in central Iraq, September 2007. Mil Med. 2008;173:949-53.

13. Newman ENC, Johnstone $P$, Bridge $H$, Wright $D$, Jameson $L$, Bosworth $A$, et al. Seroconversion for infectious pathogens among UK military personnel deployed to Afghanistan, 2008-2011. Emerg Infect Dis. 2014;20:2015-22

14. Shiraly R, Khosravi A, Farahangiz S. Seroprevalence of sandfly fever virus infection in military personnel on the western border of Iran. J Infect Public Health. 2017;10:59-63.

15. Poeppl W, Herkner H, Tobudic S, Faas A, Auer H, Mooseder G, et al. Seroprevalence and asymptomatic carriage of Leishmania spp. in Austria, a non-endemic European country. Clin Microbiol Infect. 2013;19:572-7.

16. Obwaller AG, Köhsler M, Poeppl W, Herkner H, Mooseder G, Aspöck H, et al. Leishmania infections in Austrian soldiers returning from military missions abroad: a cross-sectional study. Clin Microbiol Infect. 2018;24:1100.

17. Hukić M, Salimović-Bešić I. Sandfly_pappataci fever in Bosnia and Herzegovina: the new-old disease. Bosn J Basic Med Sci. 2009;9:39-43.

18. Venturi G, Marchi A, Fiorentini C, Ramadani N, Quaglio G, Kalaveshi A, et al. Prevalence of antibodies to phleboviruses and flaviviruses in Peja, Kosovo. Clin Microbiol Infect. 2011;17:1180-2.

19. Ayhan N, Sherifi K, Taraku A, Bërxholi K, Charrel RN. High rates of neutralizing antibodies to toscana and sandfly fever sicilian viruses in livestock, Kosovo. Emerg Infect Dis. 2017:23:989-92.

20. Ergünay K, Saygan MB, Aydoǧan S, Lo MM, Weidmann M, Dilcher M, et al. Sandfly fever virus activity in central/northern Anatolia, Turkey: first report of Toscana virus infections. Clin Microbiol Infect. 2011;17:575-81.

21. Barakat AM, Smura T, Kuivanen S, Huhtamo E, Kurkela S, Putkuri N, et al. The presence and seroprevalence of arthropod-borne viruses in Nasiriyah Governorate, southern Iraq: a cross-sectional study. Am J Trop Med Hyg. 2016:94:794-9.

22. Jacobson RL. Leishmaniasis in an era of conflict in the Middle East. VectorBorne Zoonotic Dis. 2011;11:247-58.

23. Terrosi C, Olivieri R, Bianco C, Cellesi C, Cusi MG. Age-dependent seroprevalence of Toscana virus in central Italy and correlation with the clinical profile. Clin Vaccine Immunol. 2009;16:1251-2.

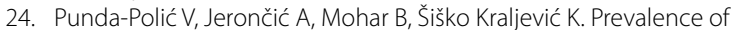
Toscana virus antibodies in residents of Croatia. Clin Microbiol Infect. 2012;18:2-5.

25. Anagnostou V, Papa A. Prevalence of antibodies to phleboviruses within the sand fly fever Naples virus species in humans, northern Greece. Clin Microbiol Infect. 2013;19:566-70.

26. Naucke TJ, Lorentz S, Rauchenwald F, Aspöck H. Phlebotomus (Transphlebotomus) mascittii Grassi, 1908, in Carinthia: first record of the occurrence of sandflies in Austria (Diptera: Psychodidae: Phlebotominae). Parasitol Res. 2011:109:1161-4.

27. Poeppl W, Obwaller AG, Weiler M, Burgmann H, Mooseder G, Lorentz S, et al. Emergence of sandflies (Phlebotominae) in Austria, a central European country. Parasitol Res. 2013;112:4231-7.

28. Obwaller AG, Poeppl W, Naucke TJ, Luksch U, Mooseder G, Aspöck H, et al. Stable populations of sandflies (Phlebotominae) in eastern Austria: a comparison of the trapping seasons 2012 and 2013. Trends Entomol. 2014:2:1-5. 
29. Riddle MS, Althoff JM, Earhart K, Monteville MR, Yingst SL, Mohareb EW, et al. Serological evidence of arboviral infection and self-reported febrile illness among U.S. troops deployed to Al Asad. Iraq. Epidemiol Infect. 2008;136:665-9.

30. Bryan JP, Iqbal M, Ksiazek TG, Ahmed A, Duncan JF, Awan B, et al. Prevalence of sand fly fever, West Nile, Crimean-Congo hemorrhagic fever, and leptospirosis antibodies in Pakistani military personnel. Mil Med. 1996;161:149-53.

31. Lazri T, Duscher G, Edelhofer R, Bytyci B, Gjino P, Joachim A. Arthropodborne parasites of dogs, especially Leishmania, in the Kosovo and Albania. Wien Klin Wochenschr. 2008;120:54-8.

32. Miščević Z, Milutinović M, Ivović V. Fauna and distribution of sandflies (Diptera, Phlebotomidae) in Yugoslavia, Croatia, Macedonia and their role in the transmission of parasitic and viral diseases. Acta Vet Brno. 1998;48:163-72.

33. Haddad N, Léger N, Sadek R. Les Phlébotomes du Liban-Inventaire faunistique. Parasite. 2003;10:99.

34. Haddad N, Saliba H, Altawil A, Villinsky J, Al-Nahhas S. Cutaneous leishmaniasis in the central provinces of Hama and Edlib in Syria: vector identification and parasite typing. Parasit Vectors. 2015;8:524.
35. Roberts DM. Circadian flight activity of Arabian sandflies (Diptera: Psychodidae) using a vehicle-mounted net. Bull Entomol Res. 1996;86:61-6.

36. Coleman RE, Burkett DA, Putnam JL, Sherwood V, Caci JB, Jennings BT, et al. Impact of phlebotomine sand flies on U.S. military operations at Tallil Air Base, Iraq: 1. Background, military situation, and development of a "Leishmaniasis Control Program". J Med Entomol. 2006;43:647-62.

37. Van Thiel PP, Leenstra T, De Vries HJ, Van Der Sluis A, Van Gool T, Krull AC, et al. Cutaneous leishmaniasis (Leishmania major infection) in Dutch troops deployed in northern Afghanistan: epidemiology, clinical aspects, and treatment. Am J Trop Med Hyg. 2010;83:1295-300.

\section{Publisher's Note}

Springer Nature remains neutral with regard to jurisdictional claims in published maps and institutional affiliations.
Ready to submit your research? Choose BMC and benefit from:

- fast, convenient online submission

- thorough peer review by experienced researchers in your field

- rapid publication on acceptance

- support for research data, including large and complex data types

- gold Open Access which fosters wider collaboration and increased citations

- maximum visibility for your research: over $100 \mathrm{M}$ website views per year

At BMC, research is always in progress.

Learn more biomedcentral.com/submissions 